\title{
イラン地区（Deiramanistan, Gilan）における古代のヤジリ*
}

\author{
（明和 37 年: 12 月 15 日受理）
}

$$
\text { 道野鹤松材 }
$$

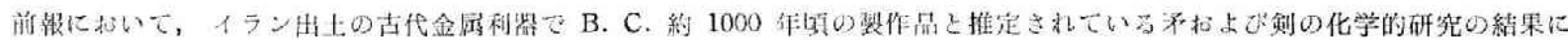

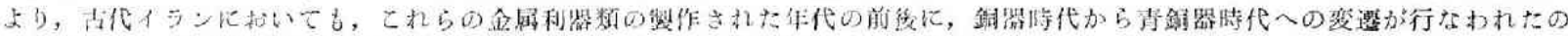

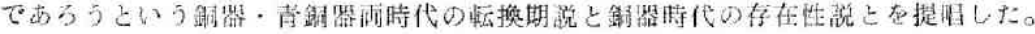

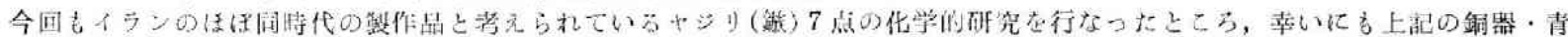

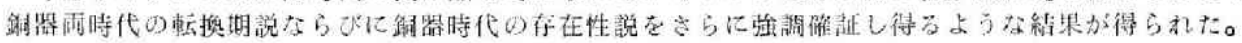

\section{1 緒言}

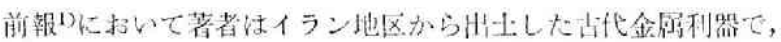
B. C. 約 1000 行项の製作品と推定さ机ている矛打よび刢合計 6

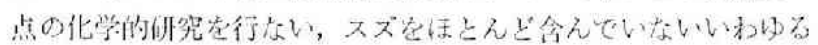

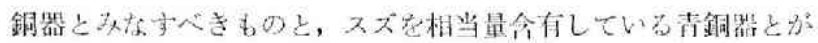

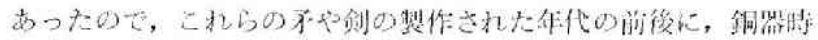

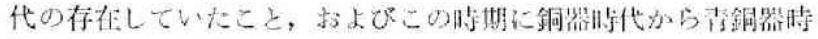

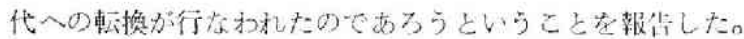

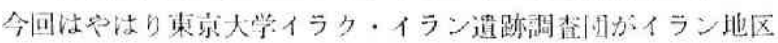

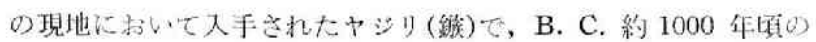

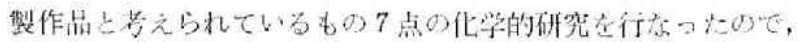
その結果を城告なることと少る。

\section{2 研 究 資 料}

研究に供した资料如束京大学イラク・イラン造跡調查网がイラ

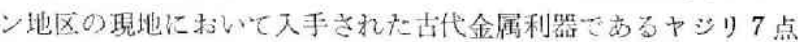
で，その整作年代枕いずれる B. C. 彴 1000 年頃のものと推定 されているものてある(四1)。

\section{3 実験}

\section{1 分析方法}

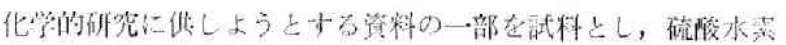

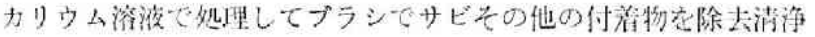

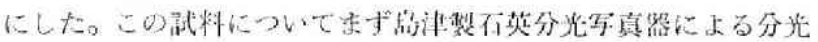

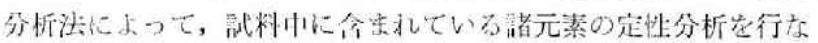

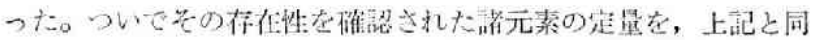

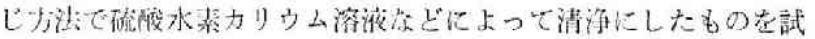

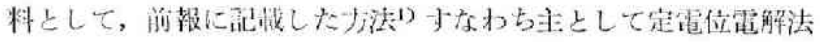

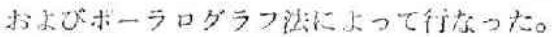

\section{2 分析結果}

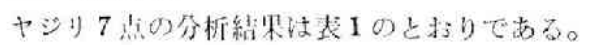

$$
4 \text { 考察 }
$$

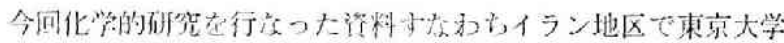

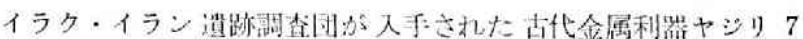

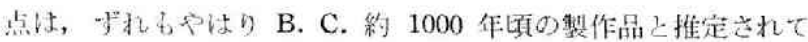

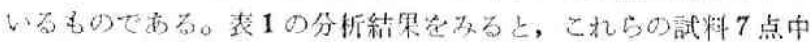

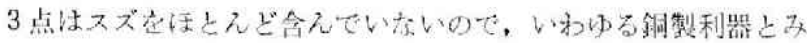
なすべき部類のものであり，他の 4 点はスズを相当量合有してい る青铜製利與をあることかわかった。したかって前報において述 ベたように，イラン地区においてはＢ．C. 1000 年頃に铜器時代

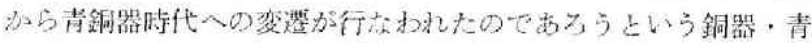

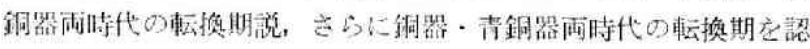
ある以上は，この地区にあってもこの年代まで銅器時代が依然之 して存䍃していたものとみるペきでらうという銅器時代の存在

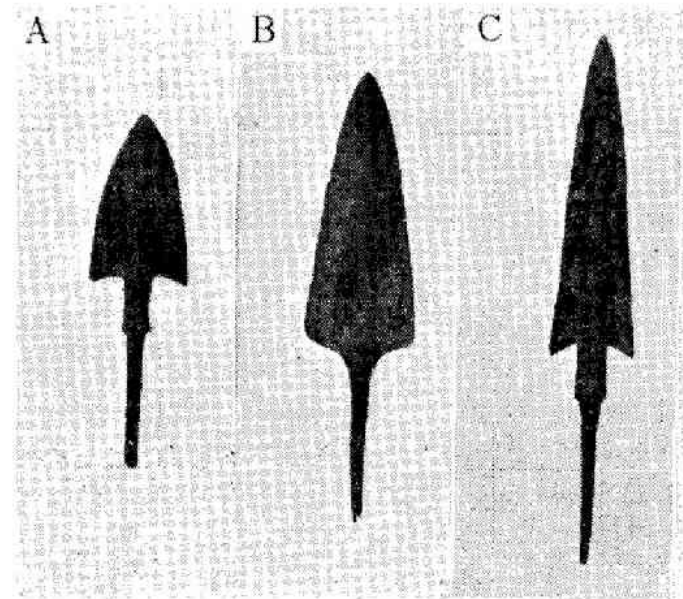

D

E
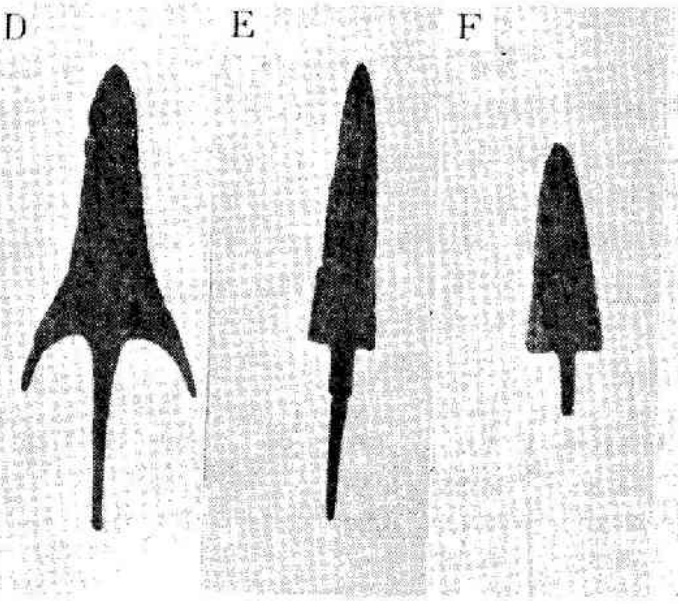

G

図1+ショ (Deiramanistan, Gilan, Iran 出土)

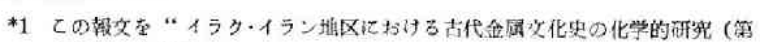
2 報) ”とする。

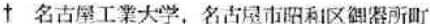

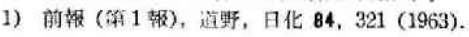


性説を今回の化学的研究の結果からも益々確缌することか゚できた わけである。

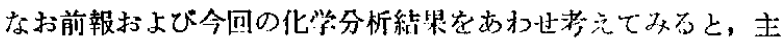
成分である銅，あるいは銅とスズ以外に，不純物として混入して いる夾雑物の種類や量はきわめて少なく，銅の純度がかなり高い ことに気がつく。すなわち鉄，七秋，アンチモン抢上びニッケル などがほとんど含まれておらず，全は分光分析によってさえも倹 出できなかった。とくにヤジリ A はほとてど不純物を合をず銅 99.88\%で化学的にも純銅に近いものであった。このことは古代 のイラン地区における銅治金の㗄源が純度ならびに品位のかなり 高いものであったことを物玨っているものと思われる。古代中国 の銅製ならびに 青銅製の 金属器類には往々にして鉄㔚よびヒ素 その他の 元素類が 相当量含有されていることがあったし，金は 分光分析法によってほとんどすべての場合，か子かではあるが 検出されているのにくらべると，いささかその趣き裂にしてい る。

以上のような諸点を考え合わせて, 藷者はさらにつぎのような 見解を抱くにいたった。すなおちこの地区の古代の初期における 銅の資源はおそらく自然界に遊離状態で存在していた自然銅か, あるいはこれに随伴して産出する可能性の多い酸化銅系統（炭酸 銅や塭基性炭酸銅などをむ含む）の鉱物または鉱石であり，硫化 鉱系統のものではなかったのではあるまいか。自然銅や酸化銅系 統の鉣物または鉣石を原料として銅を得ておったものをすると， 硫化銅系統のそれよりも鉄や七素その他の不純物の混入する機会 が少ないと思われる。さらに現在では硫化銅系統の鉱石，おむに 黄銅鍍を資源として銅治金が行なわれているが，銅治金の起源を 歴史的に考察すると，古代人注抢そらく自然界に存在し有绝で人 目につきやすい自然銅をまず採取し，これを材料として銅製品を
つくっておったもの思われる。ついで比較的選元されや-すい陵化 銅系統の鉱物または鋝石を原料として銅治金密行ない，その後に

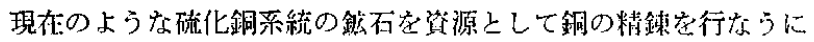
いたったものと想像される。すなわる天然に既出吉る自然銅また

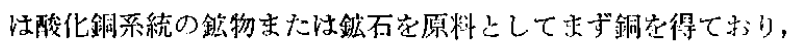

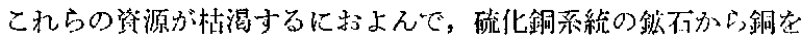

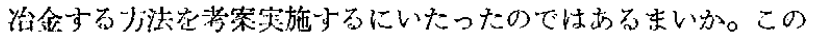

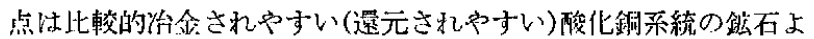

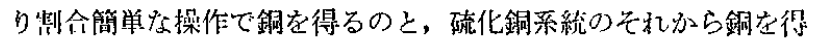

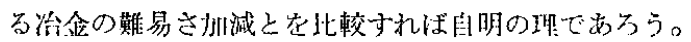

な打銅治金と鉄治金の難易さについても，現在のように，銅を 硫化銅系統の鉱石方ら得る才法と, 鉄它酸化鉄系統の鉱不吕ら治 金する才法とを比較すれば，あるいは鉄治金のオが容易であるか も知れないが，上に述べたように古代に才いて銅总方ず酸化銅系 統の鉱石を原料として治金して扔ったものと才れば，酸化鉄より の鉄治全よりもはるかに容易に行なわれたであるうと思われる。 このことは銅器ならびに青銅器の㥜と鉄器の登場との時機の新 旧, さらに銅器時代または青銅器時代上鉄器時代との発生順序を 論ずる場合にす，見逃がすことのできない胃解の一つであろう。 かく考えると考古学者が従来考えているように，物質交明はやは り石製利器を使用した石器時代汃ら金属利器使用の時代に入り, まず銅器時代が出現し, さらに青銅器時代を経て鉄器洔代に移行 し現在にいたっているとの考え方は妥当なものといたよう。

終りに本研究を行なうにあたって，期重な资料の御挺供を睗わ つた東京大学イラク・イラン遗跡調查㜀の方々に整心ょり深甚な 謝意を表する。な招また実験遂行に際して，御助力を惜しまれな 加つた名古屋工業大学助教掜理学博上中川元吉氏にも併わせて謝 意を表する。 